\title{
Comment
}

\section{THE IMPACT OF SHELLEY v. KRAEMER ON THE STATE ACTION CONCEPT}

Shelley v. Kraemer, ${ }^{1}$ prohibiting the granting of an injunction to restrain a violation of a racially restrictive covenant, promulgated the doctrine that judicial enforcement of private action, when similar state activity would be forbidden by the fourteenth amendment, is also a violation of the fourteenth amendment. This decision raises the issue of whether we are willing to accept the proposition that every time a court gives effect to, or fails to provide a remedy against, a private restriction of a right guaranteed by the fourteenth amendment, "state action" has occured. The imphications of this case have caused grave concern, and this umsgiving has been reflected in the treatment of Shelley $v$. Kraemer by subsequent decisions.

This Comment will present (1) a review of the "state action" concept prior to Shelley, (2) an analysis of the doctrine of Shelley v. Kraemer and its logical implications, (3) a presentation of the treatment of the doctrine by subsequent cases and (4) suggestions of the problems created and a possible solution, though without any atteinpt to be definitive.

\section{"State Action" and the Fourteenth Amendment}

Any analysis of the fourteenth amendment ${ }^{2}$ must begin with the understanding that its prohibitions apply only to "state action," not to the acts of private persons. ${ }^{3}$

State action under the fourteenth amendment was early recognized to include not only the actions of state legislatures, ${ }^{4}$ but actions of the executive ${ }^{5}$ and judicial ${ }^{8}$ branches, as well as the activities of political subdivisions of the state.

1334 U.S. 1 (1948).

2 U.S. Const, amend. XIV: "Section 1. All persons born or naturalized in the United States, and subject to the jurisdiction thereof, are citizens of the United States and of the State wherein they reside. No State shall make or enforce any law which shall abridge the privileges or immunities of citizens of the United States; nor shall any State deprive any person of life, liberty, or property, without due process of law; nor deny any person within its jurisdiction the equal protection of the laws.

".....

"Section 5. The Congress shall have power to enforce, by appropriate legislation, the provisions of this article."

3 Civil Rights Cases, 109 U.S. 3 (1883); United States v. Harris, 106 U.S. 629 (1882); Virginia v. Rives, 100 U.S. 313, 318 (1879) (dictun1) ; United States v. Cruikshank, 92 U.S. 542 (1875) ; Powe v. United States, 109 F.2d 147 (5th Cir. 1940), cert. denied, 309 U.S. 679 (1940); see Barnett, What Is "State" Action under the Fourteenth, Fifteenth, and Nineteenth Amendments of the Constitution?, 24 ORE. L. REv. 227 (1945); State Action and the Enabling Clatwe of the Fourteenth Amendment, 44 IrL. L. Rev. 199 (1949) ; Comment, 96 U. PA. L. Rev. 402 (1948) ; Note, 24 N.Y.U.L.Q. REv. 227 (1949).

4 Strauder v. West Virginia, 100 U.S. 303 (1879); accord, Cantwell v. Connecticut, 310 U.S. 296 (1940) ; Nixon v. Herndon, 273 U.S. 536 (1927) ; Truax v. Corrigan, 257 U.S. 312 (1921).

5 See Board of Education v. Barnette, 319 U.S. 624 (1943) ; Smith v. Illinois Bell Tel. Co., 270 U.S. 587 (1926).

${ }^{6}$ Ex parte Virginia, 100 U.S. 339 (1879) ; accord, Lee v. Mississippi, 332 U.S. 742 (1948); Cafeteria Umion v. Angelos, 320 U.S. 293 (1943); Bridges v. California, 314 U.S. 252 (1941); American Federation of Labor v. Swing, 312 U.S. 321 (1941) ; Cantwell v. Connecticut, 310 
However, alongside these apparent situations of applicability, the courts prior to Shelley v. Kraemer had broadened the definition of the state action doctrine in order to give greater effect to the amendment: ${ }^{8}$ (1) State action was held to include situations where state officials acted either in violation of or in excess of their authority ("color of law" theory), ${ }^{9}$ and (2) state action was found to include even the acts of private persons under particular circumstances ("instrumentality" theory)..$^{10}$

The rationale of the "color of law" doctrine is that state officials, even when acting without authority, are so clothed with governmental power that they can effectively deprive persons of rights guaranteed under the fourteenth amendment. Acceptance of this doctrine was not immediate ${ }^{11}$ because of an obvious dilemma: if the state has given no authority, logically the state cannot be considered to have acted. However, this position has been rejected on the ground that where, by virtue of their general authority to act for the state, persons have within their power the use of the means of government, the protection of the amendment is necessary against the unlawful means. ${ }^{12}$

The reasoming behind the instrumentality theory, somewhat akin to the "color of law" approach, is that admittedly private persons, as distinguished from state officials, are sometimes in such a position that the "means of government" are open to them so that they also must be placed under the same constitutional restrictions as the government. The major difficulty of this doctrine is the problem of identifying the standards by which "private action" is converted into "state action" without obliterating the distmction between the two. As a pre-

U.S. 296 (1940); Powell v. Alabama, 287 U.S. 45 (1932); Brinkerhoff-Faris Co. v. Hill, 281 U.S. 673 (1930); Carter v. Texas, 177 U.S. 442 (1900); Scott v. McNeal, 154 U.S. 34 (1894); see Twining v. New Jersey, 211 U.S. 78 (1908).

7 Yick Wo v. Hopkins, 118 U.S. 356 (1886); accord, Lovell v. City of Griffin, 303 U.S. 444 (1938); Buchanan v. Warley, 245 U.S. 60 (1917).

8 See, generally, HALE, FREEDOM THROUGH LAW C. XI (1952), for a discussion of the development of the state action concept in restricting private activity.

${ }^{9}$ Iowa-Des Moines Bank v. Bennett, 284 U.S. 239 (1931); Greene v. Louis \& Interurban R.R., 244 U.S. 499 (1917) ; Home Tel. \& Tel. Co. v. Los Angeles, 227 U.S. 278 (1913); see Screws v. Umited States, 325 U.S. 91 (1945). But see the concurring opinion of Frankfurter, J., in Snowden v. Hughes, 321 U.S. 1, 16-17 (1944).

10 See, e.g., Marsh v. Alabama, 326 U.S. 501 (1946); Rice v. Elmore, 165 F.2d 387 (4th Cir. 1947), cert. denied, 333 U.S. 875 (1948); Kerr v. Enoch Pratt Free Library, 149 F.2d 212 (4th Cir. 1945), cert. denied, 326 U.S. 721 (1945); Lawrence v. Hancock, 76 F. Supp. 1004 (S.D.W.Va. 1948) ; Kern v. City Comm'rs of Newton, 151 Kan. 565, 100 P.2d 709 (1940); Culver v. City of Warren, 84 Ohio App. 373, 83 N.E.2d 82 (1948).

11 Savannah, Thnnderbolt \& I. of H. Ry. v. Savannah, 198 U.S. 392, 396 (1905) (dictuin); Barney v. City of New York, 193 U.S. 430 (1904); Huntington v. City of New York, 193 U.S. 441 (1904); Arrowsmith v. Harmoning, 118 U.S. 194 (1886) (semble). For criticisin of the "color of law" doctrine, see Comment, 96 U. PA. L. Rev. 402, 405-08 (1948).

Compare the "color of law" doctrine to the "stripping doctrine" of Ex parte Young, 209 U.S. 123 (1908). To avoid the prohibitions of the eleventh amendment to the Federal Constitution the courts permitted suits to restrain state officers from carrying out state laws alleged to be unconstitutional. The plaintiff's theory of action was that an official had no authority to carry out an unconstitutional law and so the official had become "stripped" of his official capacity and was being sued in his private capacity. This is contrary to the "color of law" doctrine, but apparently each theory has been kept in its own bailiwick so that no occasion has arisen to resolve the conflict between them. See Iowa-Des Momes Bank v. Bennett, 284 U.S. 239, 246 n.5 (1931).

12 Cases cited note 9 supra. For a discussion of the conflict concerning the "color of law" doctrine, see Barnett, What Is "State Action" under the Fourteenth, Fifteenth, and Nineteenth Amendments of the Constitution?, 24 ORE. L. REv. 227 (1945). 
liminary step three questions can be asked. The affirmative answer to any of these is a warning at least that the situation is within the problem area of the instrumentality theory:13 (1) Did the government grant any aid to the private person ${ }^{11}$ (2) Did the government give any authority to him? (3) Is he carrying on a "function of a governmental nature?" Given an affirmative answer, then the difficult task ensues of having to determine whether there is enough aid or "authority" or "function" to make the private person into some sort of "state instrument" by reason of an affinity to the government.

Consider the inter-play of factors arising from to similar cases where affirmative answers to the first and third questions are possible. In Kern v. City Comm'rs of Newton ${ }^{15}$ a swimming pool built at public expense was leased for an entire season to a private party who refused admission to Negroes. Plaintiff, a Negro, sued the city for a writ of mandamus to compel the city to prevent such discrimmation. The city defended on the fact that the pool was leased to a private party. The Kansas Supreme Court held that the discrimmation violated the fourteenth amendment and that mandamus was a proper remedy. Despite the fact that this was a bona fide lease to a private party and the lessee had the full duties of upkeep and control, the situation was treated as if the pool had retained its pubhic characteristics. ${ }^{16}$ At the other extreme, in Harris v. St. Louis ${ }^{17}$ the Missouri Court of Appeals refused to find state action in the discrimination practiced by the short-term lessee of a city auditorium. The city itself practiced no discrimination since it leased to both white and Negro groups, ${ }^{18}$ and the brevity of the lease ("several weeks") plus the lessee's limited control of the auditorium were not enough to impute any "governmental function" to the lessee. In each of these cases government aid was provided in the leasing of government property; the character of the leasehold determined whether there was a "goverumental function."10

13 See Note, 29 IND. L.J. 125 (1953). For a discussion of the constitutional problem of the delegation of public authority to private groups, see Comment, 67 Harv. L. REv. 1398 (1954). The situations discussed are ones where the instrumentality theory could well be applicable.

${ }^{14}$ No decision was found where the granting of government aid without more was beld sufficient to give effect to the instrumentality theory.

15151 Kan. 565, 100 P.2d 709 (1940); accord, Lawrence v. Hancock, 76 F. Supp. 1004 (S.D.W.Va. 1948) ; Culver v. City of Warren, 84 Ohio App. 373, 83 N.E.2d 82 (1948) (decided after Shelley v. Kraemer). Compare Kerr v. Enoch Pratt Free Library, 149 F.2d 212 (4th Cir. 1945), cert. denied, 326 U.S. 721 (1945), with Norris v. Baltimore, 78 F. Supp. 451 (D. Md. 1948) (decided after Shelley v. Kraemer).

16 However, plaintiff's motion for a judgment on the pleadings was denied due to a controversy on certain issues of fact that had to be determined before mandamus could issue.

17233 Mo. App. 911, 111 S.W.2d 995 (1938).

18 Was the failure of the city to promulgate regulations forbidding discrimimation "state action"? See Hyman, Segregation and the Fourteenth Amendment, 4 VAND. L. REv. 555, 571-72 (1951); Ming, Racial Restrictions and the Fourteenth Amendment: The Restrictive Covenant Cases, 16 U. CHr. L. Rev. 203, 235 (1949); Comment, State Action and the Enabling Clause of the Fourteenth Amendment, 44 ILI. L. REv. 199, 202-11 (1949); Comment, 96 U. PA. L. Rev. 402, 412-13 (1948). But see Comment, 17 U. CIN. L. Rev. 277, 281-82 (1948).

10 An additional factor, at first not isolated from the others, has become recognized as an independent consideration in the leasing cases: Was the intent to discriminate a primary motivation in making the lease? Compare Tate v. Department of Conservation and Development, 133 F. Supp. 53 (E.D. Va. 1955) (discrimination invalidated because intent to discriminate was primary factor in making the lease), with Easterly v. Dempster, 112 F. Supp. 214 (E.D. Tenn. 1953) (financial reasons being the motive for the lease, discrimination by lesseo not restrained); see Note, 42 VA. L. Rev. 291 (1956). Should intent be a factor when in fact -intent or no-property bought with public funds is leased to a private party and discrimination takes place on what is still public property? 
A striking example of a grant of authority converting the actions of a private party into governinental action is shown in Betts v. Easley. ${ }^{20}$ Anti-Negro discrimination practiced by a union certified under the Railway Labor Act as the sole bargaining agent of all carmen, including Negroes, in a certain shop was held by the Kansas Supreme Court to be "governmental action" in violation of the fifth amendment. ${ }^{21}$ Because the authority the union had over the Negro carmen arose by virtue of the government certification, the union had in effect become an agent of the government in this matter and subject to constitutional himitations.

The most significant developments under the instrumentality theory are found in the primary election cases ${ }^{22}$ and in Marsh $v$. Alabama. ${ }^{23}$ In the former the continuing attempt of southern state Democratic parties to keep Negroes out of primary election participation by step-by-step withdrawal of state collaboration with the parties has been paralleled by concurrent step-by-step extension of the instrumentality doctrine to meet the challenge. The logical culmination prior to Shelley v. Kraemer was Rice v. Elmore. ${ }^{24}$ In South Carolina all statutes regulating primary elections had been repealed so that there was neither state prohibition of Negro voting, ${ }^{25}$ state authorization of political parties to choose their own members, ${ }^{26}$ a state requirelnent for holding primaries, ${ }^{27}$ nor state regulation even if a primary were held. ${ }^{28}$ Nonetheless, relying on Smith $v$. Allwright ${ }^{2 \theta}$ for the proposition that it was not so much the actual state collaboration that was fundamental as the nature of the goverminental function served by the political party in the Democratic primary, party rules barring Negroes from voting were held by the United States Court of Appeals for the Fourth Circuit to be violations of the fourteenth and fifteenth amendments. ${ }^{30}$

Undoubtedly the most provocative case raising the issue of the instrumen-

20161 Kan. 459, 169 P.2d 831 (1946); see Steele v. Louisville \& N. Ry., 323 U.S. 192, 198 (dictum), and Murphy, J., concurring at 208 (1944).

21 As with the fourteenth amendment, the fifth amendment does not prohibit the acts of private persons. Corrigan v. Buckley, 271 U.S. 323, 330 (1926). The problem of whether there has been private or governmental action is equally present. See Betts v. Easley, 161 Kan. 459, 467, 169 P.2d 831, 838 (1946). But see Noreen v. Van Dyke, 133 F. Supp. 142, 146-47 (D. Minn. 1955) (dictum), where actions by a government official in his "capacity as an employer" were said not to be encompassed by the fifth amendment. Would not this mean that the scope of "state action" under the fourteenth amendment is broader than that of "governmental action" under the fifth?

22 The important pre-Shelley cases include Smith v. Allwright, 321 U.S. 649 (1944); Rice v. Elmore, 165 F.2d 387 (4th Cir. 1947), cert. denied, 333 U.S. 875 (1948); Chapman v. King, 154 F.2d 460 (5th Cir. 1946), cert. denied, 327 U.S. 800 (1946). See note 30 infra for a discussion of the post-Shelley decisions.

23326 U.S. 501 (1946).

24165 F.2d 387 (4th Cir. 1947), cert. denied, 333 U.S. 875 (1948).

25 See Nixon v. Herndon, 273 U.S. 536 (1927).

26 See Nixon v. Condon, 286 U.S. 73 (1932).

27 See Smith v. Allwright, 321 U.S. 649 (1944).

28 See Chapman v. King, 154 F.2d 460 (5th Cir. 1946), cert. denied, 327 U.S. 800 (1946). 20321 U.S. 649 (1944).

30 But see Chapman v. King, 154 F.2d 460 (5th Cir. 1946), cert.denied, 327 U.S. 800 (1946). This decision finding state action was based squarely on state collaboration and expressly rejected criteria such as were relied on in Rice v. Elmore. The latter decision, written by Parker, J., voiced disapproval of the Chapman approach. Thus up to Shelley $v$. Kraemer the instrumentality theory had failed to determine in the election field whether the action of the individuals per se or the state collaboration created the "state action."

After Shelley $v$. Kraener Judge Parker reasserted his position in Rice $v$. Elmore by hold- 
tality theory is Marsh v. Alabama. ${ }^{31}$ The community of Chickasaw, Alabama, was a company-owned town, a few feet off the public highway but on private property. The community provided complete hiving and business facilities for its inhabitants. The managers of the town maintained the right to prohibit any solicitation within Chickasaw unless a permit were obtained from them. After a refusal of a permit, plaintiff continued to distribute religious literature on a street of the town and was convicted under a state criminal trespass statute. The United States Supreme Court reversed the conviction, finding a violation of the fourteenth amendment. The problem is, wlat was the violation? Was it the court conviction based on the acts of private persons, ${ }^{32}$ or was it the refusal of the managers to grant a permit ${ }^{33}$ The lolding of the case was: ${ }^{34}$

Insofar as the State has attempted to impose criminal punishment on appellant for undertaking to distribute religious literature in a company town, its action cannot stand.

But the decision speaks in broader terms: ${ }^{35}$

Whether a corporation or a municipality owns or possesses the town the public in either case has an identical interest in the functioning of the community in such a manner that the clrannels of communication remain free. ... The managers appointed by the corporation cannot curtail the liberty of press and religion of these people consistently with the purposes of the Constitutional guarantees, and a state statute, as the one here involved, which enforces such action by criminally punishing those who attempt to distribute religious literature clearly violates the First and Fourteenth Amendments .....

Since the activities of individuals, without more, cannot violate the fourteenth amendinent, ${ }^{36}$ the town managers inust liave been "governinental" in some manner to be able to "curtail the liberty of press and religion." 37

ing that discrimination practiced by private pohtical clubs, where in fact the club clections determined the winners in both the party primaries and the general election, was in essence no different than discrimination by the Democratic party and hence a violation of the fiftecnth amendment. Baskin v. Brown, 174 F.2d 391 (4th Cir. 1949).

Terry v. Adams, 345 U.S. 461 (1953), would appear to uphold Judge Parker. Seven justices in two opinions agreed that the acts of private electoral associations themselves could be state action. Though for different reasons Justice Frankfurter's position is akin to that taken by the court in Chapman v. King, while Justice Minton's dissent disagreed with the idea that just because a private electoral association was successiul it should be placed in the state action category. Does the state action cliaracterization depend on the success of the organization involved?

31326 U.S. 501 (1946). But cf. Watchtower Bible \& Tract Soc'y v. Metropolitan Llfe Ins. Co., 188 Misc. 978,69 N.Y.S.2d. 385 (Sup. Ct. 1947).

32 This would place the case squarely as precedent for Shelley v. Kraemer. See Comment, 45 Micr. L. REv. 733 (1947); cf. Lathrop, The Racial Covenant Cases, 1948 WIs. L. REv. 508. Bits see Note, 44 Micr. L. REv. 848, 852 (1946).

Shelley uses Marsh v. Alabama in this sense: "[I]t would appear beyond question that the power of the State to create and enforce property interests must be exercised within the boundaries defined by the Fourteenth Amendment. Cf. Marsh v. Alabama ...." Shelley v. Kraemer, 334 U.S. 1, 22 (1948). (Emphasis added.)

33 This would equate the action of the managers, private persons, to that of a municipality refusing to grant permits. Cf. Martin v. Struthers, 319 U.S. 141 (1943). Sce Notes, 44 MICH. L. REv. 848 (1946), 1947 WIs. I. REv. 121, I Wro. L.J. 142 (1947).

84 Marsh v. Alabama, 326 U.S. 501, 509 (1946). (Emphasis added.)

35 Id. at 507-08. (Emphasis added.)

36 "[C]ivil rights . . . cannot be impaired by the wrongful acts of individuals, unsupported by [the] State ... . The wrongful act of an individual, unsupported by such authority, is simply a private wrong, or a crime ... [R]ights remain in full force ...." The Civil Rights Cases, 109 U.S. 3, 17 (1883).

37 If this is the meaning of Marsh v. Alabama, then, keeping Rice v. Elmore in mind, the existing scope of the state action doctrine presented the Supreme Court with a possible 
Thus prior to Shelley v. Kraemer the state action doctrine of the fourteenth amendment had been considerably broadened without being rendered meaningless. Despite the fact that "state action" had burst out of traditional bounds, the doctrine was so delineated that the scope of what was permissible "private action," not within the restrictions of the fourteenth amendment, was still foremost and without any real danger of obliteration.

\section{Shelley v. Kraemer-The New Concept of "Judicial Enforcement"}

The close of World War II forced the United States to face one of its greatest social problems, residential racial segregation, now aggravated by the general post-war housing shortage. ${ }^{38}$ The long legal battle to overcome such discrimination was climaxed in Shelley v. Kraemer.

When discriminatory city zoning ordinances were declared unconstitutional, ${ }^{39}$ the restrictive covenant ${ }^{40}$ became a substitute. Property owners would band together and restrict along racial lines the future owners and occupiers of their own and each other's land. ${ }^{ \pm 1}$ Until the Shelley decision the constitutional validity of these covenants seeined firmly established. ${ }^{42}$ Limitations on the validity of

means of prohibiting restrictive covenants without the additional step taken in Shelley by characterizing restrictive covenants as a form of zoning, a governmental function. See Comments, 67 HaRv. L. REv. 1398, 1404 (1954), 61 HaRv. L. REv. 344, 349-50 (1948); cf. Village of Euclid v. Amber Realty Co., 272 U.S. 365, 387-88 (1926); Beuscher \& Morrison, Judicial Zoning Through Recent Nuisance Cases, 1955 WIs. L. REv. 440; Comment, 29 IND. L.J. 125, 136-38 (1953). This argument was presented to the Court in Shelley. E.g., Brief of the American Civil Liberties Union, Amicus Curiae, pp. 11-22, Shelley v. Kraemer, 334 U.S. 1 (1948). On the other hand, if the criminal conviction alone were the state action, then Marsh provides some precedent for the Shelley approach.

38 For a description of this problem and its results, see Kahen, Validity of Anti-Negro Restrictive Covenants: A Reconsideration of the Problem, 12 U. C\#I. L. REv. 198, 201-06 (1945) ; Ming, Racial Restrictions and the Fourteenth Amendment: The Restrictive Covenant Cases, 16 U. Cमn. L. Rev. 203, 207-09 (1949).

30 Buchanan v. Warley, 245 U.S. 60 (1917); Richmond v. Deans, 281 U.S. 704 (1930); Harmon v. Tyler, 273 U.S. 668 (1927).

40 For a discussion of the legal foundation of restrictive covenants, see Ming, Racial Restrictions and the Fourteenth Amendment: The Restrictive Covenant Cases, $16 \mathrm{U} . \mathrm{C}$ \#I. $\mathrm{L}$. REv. 203, 209 n.21 (1949).

${ }^{41}$ See Kahen, Validity of Anti-Negro Restrictive Covenants: A Reconsideration of the Problem, 12 U. Cㅍ․ L. Rsv. 198 (1945). But see Frank, The United States Supreme Court: 1947-48, 16 U. CEr. L. REv. 1, 24-26 (1948), who argues that such covenants are only ai fourth line of defense for the covenantor: Real estate boards" "codes of ethics," the difficulty of the Negro purchasers to obtain financing, and community pressure on the white vendor have usually been effective without enforcement of the covenants.

It is to be noted that such covenants are not directed solely at Negroes. See Ming, Racial Restrictions and the Fourteenth Amendment: The Restrictive Covenant Cases, $16 \mathrm{U}$. CHr. L. REv. 203, 206 n.15 (1949).

42 Historically, it could have been otherwise. The first reported case dealing with racially restrictive covenants is Gandolfo v. Hartman, 49 Fed. 181 (C.C.S.D. Cal. 1892), where the enforcement of an anti-Chinese restriction was held to violate the fourteenth amendment. The decision was not followed and the constitutionality of racially restrictive covenants was accepted in state courts. See, e.g., Chandler v. Zeigler, 88 Colo. 1, 291 Pac. 822 (1930); Meade v. Dennistone, 173 Md. 295, 196 Atl. 330 (1938); Mrsa v. Reynolds, 317 Mich. 632, 27 N.W.2d. 40 (1947); Doherty v. Rice, 240 Wis, 389, 3 N.W.2d 734 (1942). This position had been strengthened by Corrigan v. Buckley, 271 U.S. 323 (1926), arising in the District of Columbia. In a suit to enjoin a violation of a covenant defendants' motions to dismiss, based on the grounds that the covenants involved violated the fifth, thirteenth and fourteenth amendments, were denied. The United States Court of Appeals for the District of Columbia affirmed. Corrigan v. Buckley, 299 Fed. 899 (D.C. Cir. 1924). An appeal to the 
racially restrictive covenants, none of which prevented their use, were solely on non-constitutional grounds. ${ }^{43}$ However, a new anti-covenant argument was developed. It was urged that the judicial enforcement of the covenants was barred as being prohibited state action under the fourteenth amendment.

While very similar to the settled application of the rule that judicial activity in violation of the fourteenth amendment was invalid, this new argument was distmct in one way. In the cases exemplifying "orthodox" judicial violation the prolibited activity was practiced by the judge himself. For example, in the famous decision of Powell v. Alabama $a^{44}$ failure of the judge to allow defendants adequate counsel was found to be a denial of due process. However, in this new approach the discrimination originated with private persons; the impartial "enforcement" of the discrimination had to be taimted by it and become prohibited. To overcome the distinction Professor D. O. McGovney of the University of California, pointing out that the effect of the judgment of the court is as discriminatory as the private covenant it enforces, argued by analogy. ${ }^{45}$ He claimed that if a statute

Supreme Court was dismissed for want of jurisdiction. Corrigan v. Buckley, 271 U.S. 323 (1926). Despite the fact that the property involved was in the District of Columbia, so that the fourteenth amendment was inapplicable, the case was often cited for the proposition that racially restrictive covenants did not violate that amendment. See, e.g., the cases cited in this note, supra. Possibly this was because the Court also ignored this fact, excluding the fourteenth amendment solely on the ground that the covenants were a result of private, not state, action. Corrigan v. Buckley, supra at 330 .

For a discussion of the litigational history of racially restrictive covenants, see McGovney, Racial Residential Segregation by State Court Enforcement of Restrictive Agreements, Covenants or Conditions in Deeds Is Unconstitutional, 33 CALIF. L. REv. 5, 7-15 (1945); Crooks, The Racial Covenant Cases, 37 GEo. L.J. 514, 515-18 (1949); Miller, Race Restrictions on Ownership or Occupancy of Land, 7 LAw. Gund. REv. 99 (1947).

43 The major limitations were the common law rule against restraints on alienation and the "change of neighborhood" doctrine.

The rule against restraints on alienation led some states to declare invalid racial covenants preventing the sale or leasing of property whereas covenants prohibiting the "use and occupation" by Negroes were held valid. Other states refused to apply the rule so that both types were valid. See McGovney, Racial Residential Segregation by State Court Inforcement of Restrictive Agreements, Covenants or Conditions in Deed's Is Unconstitutional, 22 CALI. L. REv. 5, 8-11 (1945).

The "change of neighborhood" doctrine states that though a restrictive covenant be valid, equity will refuse to enforce it if the neighborhood has so changed that there would be no purpose to its enforcement. See 3 TrFfany, Rear Property $\$ 875$ (3d ed. 1939). As McGovney, supra at 12 , points out, this doctrine is less to aid the excluded race as to relieve the covenantor or his successor of a "white elephant."

44287 U.S. 45 (1932). Other examples include racial discrimination by a judge in the selection of jurors (Ex parte Virginia, 100 U.S. 339 (1879)) ; refusal by the judge to allow defendant to prove a confession was coerced (Lee v. Mississippi, 332 U.S. 742 (1948)) ; and judicial enforcement of common law policy restricting picketing (American Federation of Labor v. Swing, 312 U.S. 321 (1941) ). Cases concerning state common law policy, of which Swing is an example, come close to the judicial enforcement theory but are still different. The violative common law policy originates with and is enforced by the judge; in the judicial enforcement theory the violative action originates with private parties.

45 McGovney, Racial Residential Segregation by State Court Inforcement of Restrictive Agreements, Covenants or Conditions in Deeds Is Unconstitutional, 33 CaIrF. L. REv. 5 (1945). Compare Professor McGovney's approach, arguments and analysis with the decision in Shelley v. Kraemer, 334 U.S. 1 (1948). Other articles arguing the McGovney thesis include Hale, Rights under the Fourteenth and Fifteenth Anendments against Injuries Inflicted by Private Individuals, 6 LAw. Gund Rev. 627 (1946); Kalien, Validity of Anti-Negro Restrictive Covenants: A Reconsideration of the Problem, 12 U. CHI. L. REv. 198 (1945) ; Miller, Race Restrictions on Ownership or Occupancy of Land, 7 LAw. Gumb Rev. 99 (1947) ; Vaughn, Resisting the Enforcentent by Courts of Restrictive Covenants Based on Race, 5 NaT'L B.J. 381 (1947). Contra, Coinment, 45 MICH. L. Rev. 733 (1947). 
were passed declaring racially restrictive covenants to be legal and enforceable this would be discriminatory state action in violation of the fourteenth amendment. Similarly, he continued, when the courts develop and apply a common law rule declaring racially restrictive covenants to be vahid and enforceable, the state is again discriminating.

This argument has been criticized elsewhere ${ }^{46}$ and so it will not be discussed here. ${ }^{47}$ It has been presented in court before Shelley and had all but unanimously been rejected. ${ }^{48}$ Nevertheless, this was the approach selected by the United States Supreme Court to emasculate the racially restrictive covenant.

Shelley v. Kraemer ${ }^{49}$ was typical of the many cases which had come before the courts regarding racially restrictive covenants..$^{50}$ The Negro defendants had purchased (and during suit had taken possession of) certam residential property subject to a racially restrictive covenant. Owners, of the neighboring property subject to the same covenant sued to restrain the Negroes from taking possession and to divest them of title. The trial court denied relief on the ground that the agreements sued upon had never become effective because all property owners in the district had not signed them. The Supreme Court of Missouri reversed, directing the trial court to grant the relief prayed for and holding that neither the covenant nor its enforcement violated the fourteenth amendment. ${ }^{51}$ The United States Supreme Court reversed, holding that while the covenant itself was valid, "judicial enforcement" of it did violate the fourteenth amendment.52

Relying on the doctrine that judicial activity is encompassed by the scope of the fourteenth amendment, the Court forged the vital link-showing that judicial

46 Comment, 45 Mrce. L. REv. 733 (1947).

47 In analyzing Professor McGovney's thesis these questions must be asked: Would a statute merely declaring racially restrictive covenants to be valid and enforceable be a violation of the fourteenth amendment? Is not the common law rule involved no more than the enforcement of private contracts with no regard to the reasons behind them? Conceptually, do we want the enforcement of private law to be considered a "state activity ?"

48 E.g., Corrigan v. Buckley, 271 U.S. 323 (1926) (dictum); Mrsa v. Reynolds, 317 Mich. 632, 27 N.W.2d 40 (1947); Northwest Civic Ass'n v. Sheldon, 317 Mich. 416, 27 N.W.2d 36 (1947) ; Ridgway v. Cockburn, 163 Misc. 511, 296 N.Y.S. 936 (1937) ; cf. Burkhardt v. Lofton, 63 Cal. App. 2d 230, 238-39, 146 P.2d 720, 724 (1944). Contra, Gandolfo v. Hartman, 49 Fed. 181 (C.C.S.D. Cal. 1892). However, it is apparent that the problem of whether judicial enforcement of racially restrictive covenants violated the fourteenth amendments was seldom considered as a separate issue by the courts. For example, the American Law Reports could catalogue only eight such cases, although Corrigan and Gandolfo were not on the particular list. Annot., 3 A.L.R.2d 466, 479 n.18 (1949).

49334 U.S. 1 (1948). The companion decision to Shelley is Hurd v. Hodge, 334 U.S. 24 (1948), where injunctive relief was sought to enforce racially restrictive covenants on property in the District of Columbia. Obviously the fourteenth amendment was inapplicable, and the Court refused to rule on the basis of the fifth amendment. Injunctive relief was refused on the grounds that judicial enforcement was "governmental action" prohibited by REV. STAT. \$ 1978 (1875), 42 U.S.C. \$1982 (1952), or, alternatively, that federal judicial enforcement of agreements which the states could not enforce under the fourteenth aniendment would violate the "public policy of the United States."

50 See, e.g., cases cited note 42 supra. For a discussion as to how these particular cases reached the Supreme Court, see Vose, NAACP Strategy in the Covenant Cases, 6 WESTERN RES. L. REv. 101 (1955).

51 Kraemer v. Shelley, 355 Mo. 814, 198 S.W.2d 679 (1946).

52 "We hold that in granting judicial enforcement of the restrictive agreements in these cases, the States have denied [defendants] . . . the equal protection of the laws and that, therefore, the action of the state courts cannot stand." Shelley v. Kraemer, 334 U.S. 1, 20 (1948).

The Michigan case of Sipes v. McGhee, 316 Mich. 614, 25 N.W.2d 638 (1947), where the facts are substantially the same as Shelley, also was reversed in the same opinion. 
enforcement of private discrimination is prohibited state action-by presenting an argument based on the effect of the judicial activity: ${ }^{53}$

[T] hese are cases in which the States have made available to [private] ... individuals the full coercive power of government to deny [defendants] ..., on the grounds of race or color, the enjoyment of property rights ..... Nor is the Amendment ineffective simply because the particular pattern of discrimination, which the State has enforced, was defined initially by the terms of a private agreement. State action [under] ... the Fourteenth Amendment, refers to the exertions of state porver in all forms. And when the effect of that action is to deny rights subject to the protection of the Fourteenth Amendment, it is the obligation of this Court to enforce the constitutional commands.

What does this reasoning imply? For some it has meant that any judicial "aid" to privately enforced activity (including a denial of remedy against such activity), when the state could not so act under the fourteenth amendment, is state action in violation of that amendment. ${ }^{54}$

But interspersed with these broad words of interpretation were words of caution: ${ }^{55}$

We conclude, therefore, that the restrictive agreements standing alone cannot be regarded as violative of any rights.... So long as the purposes of those agreements are effectuated by voluntary adherence..., it would appear clear that there has been no action by the State.... .

But here there was more. These are cases in which the purposes of the agreements were secured only by judicial enforcement of the state courts. ...

53334 U.S. at $19-20$.

54 Note these passages from Ming, Racial Restrictions and the Fourteenth Amendment: The Restrictive Covenant Cases, 16 U. CEn. L. REv. 203, 234, 235 (1949):

"For example, if a Negro presents himself for admission to a privately owned place of public accommodation, such as a hotcl, and is demied admission solcly on account of his color, it has generally been held by state courts that ... he is without remedy. [Citations omitted.] But the Restrictive Covenant cases require such a decision to meet the test of the Fourtcenth Amendment, and the Supreme Court's analysis of that Amendment should compel reversal. The decision of the state court would be 'state action' as now defined.

".....

"The issue of judicial enforcement of private segregation and exclusion might arise ... in a variety of ways. One obvious case is an action for damages by a Negro .... Or the proprietor or his servant might sue in tort if the person refused accommodations had resisted the effort to eject him .... If the decision is against the Negro, though under similar circumstances, there would have been a decision in favor of a white person, the court's action violates the federal Constitution." See also Huber, Revolution in Private Law?, 6 S.C.L.Q. 8, 25-28 (1953).

Apparently in agreement are the words of Douglas, J., dissenting in Black v. Cutter Laboratories, 351 U.S. 292, 301-02 (1956): "The Court says that the parties to a collective-bargaining agreement may make Communist Party membership 'just cause' for discharge of an employee, that discharge for that reason is mercly a matter of contract between the [parties] .... and that when the contract is enforced no federal right is infringed. I disagree with that doctrine .... I can better illustrate iny difficulty by a hypothetical case. A umion enters into a collective-bargaining agreement with an employer that allows any employee who is a Republican to be discharged for 'just cause.' Employers can, of course, hire whom they choose .... But the courts may not be implicated in such a discriminatory scheme. Once the courts put their imprimatur on such a contract, government, speaking through the juticial branch, acts. Shelley v. Kraemer, 334 U.S. 1; Barrows v. Jackson, 346 U.S. 149." (Emphasis added.) This dissenting decision was concurred in by Warren, C. J., and Black, J. See also the opinion of Justice Douglas, this time speaking for the Court, in Railway Employees' Dep't v. Hanson, 351 U.S. 225, 232 n.4 (1956).

55334 U.S. at 13-14. (Citations oumitted; emphasis added.) 
And further: ${ }^{58}$

It is clear that but for the active intervention of the state courts ... [defendants] would have been free to occupy the properties without restraint.

These are not cases ... in which the States have merely abstained from action, leaving private individuals free to impose such discrimination as they see fit.

These words have led to a search for a limit to Shelley. Granted that some form of judicial recognition of private activity is state action under the fourteenth amendment, does this apply in every case where judicial activity has become part of the scheme of private activity? Does it make a difference if suit is brought to end the private activity rather than to give it greater effectiveness? Shall the failure of a state court to give a remedy against private action be classified as similar to providing a remedy for the benefit of private action?

\section{The Subsequent Treatment of Shelley v. Kraemer}

Shelley v. Kraemer injected something new into the state action doctrine of the fourteenth amendment. Nearly a decade has elapsed since it became a part of the law of the land. Many opportunities have come before the courts to apply Shelley, yet an analysis of the decisions subsequent to Shelley v. Kraemer indicates a marked reluctance to apply its theory within its broad implications. Where the problem of private action and the fourteenth amendment has arisen the courts usually have sought to fit the case into one of the pre-Shelley doctrines. Failing in this most courts still refuse to give effect to the full scope of the decision, many of them either ignoring Shelley or summarily rejectimg it. ${ }^{57}$

Cases concerning racially restrictive covenants, ${ }^{58}$ the major exception to the general trend, have usually followed the Shelley doctrine in the broadest sense. But even here-because of the dictum in Shelley that the covenants per se were not invalid ${ }^{50}$ - the exact legal status of the covenants is still unclear. Those cases where equitable relief against covenant violations was prayed for were easily disposed of by reference to Shelley. ${ }^{00}$ The question of whether Shelley is available as a defense in suits for damages for a breach of a racially restrictive covenant ${ }^{81}$

56 Id. at 19. (Emphasis added.)

67 For examples of such summary treatment see Johnson v. Middleton, 175 F.2d 535 (7th Cir. 1949) ; Norris v. Baltimore, 78 F. Supp. 451 (D. Md. 1948); Gordon v. Gordon, 332 Mass. 197, 124 N.E.2d 228 (1953) ; Dorsey v. Stuyvesant Town Corp., 299 N.Y. 512, 87 N.E.2d 541 (1949) ; Novick v. Levitt \& Sons, 200 Misc. 694, 108 N.Y.S.2d 615 (1951) ; United States Nat'l Bank v. Snodgrass, 202 Ore. 530, 275 P.2d 860 (1954).

For examples of decisions attempting to deal with Shelley, see Rice v. Sioux City Memorial Park Cemetery, 245 Iowa 147, 60 N.W.2d 110 (1953) ; Charlotte Park and Recreation Comm'n v. Barringer, 242 N.C. 311 , 88 S.E.2d 114 (1955); Estate of Girard, Pa. Orph. Court, Phila. County (1955), 1 Race Retat. L. Rep. 325 (April 1956), aff'd en banc, 1 Race Retat. L. Rep. 340, aff'd, 25 U.S.L. WeEK 2214 (Pa. Nov. 12, 1956); $c f$. NLRB v. Pacific American Shipowners Ass'n, 218 F.2d 913, 917 n.3 (9th Cir. 1955) (separate opimon).

58 E.g., Coleman v. Stewart, 33 Cal. 2d 703, 204 P.2d 7 (1949); Tovey v. Levy, 401 III. 393, 82 N.E.2d 441 (1948); Goetz v. Smith, 191 Md. 707, 62 A.2d 602 (1948); Malicke v. Milan, 320 Mich. 65, 32 N.W.2d 353 (1948); Woytus v. Winkler, 357 Mo. 1082, 212 S.W.2d 411 (1948) ; Kemp v. Rubim, 298 N.Y. 590, 81 N.E.2d 325 (1948); see In re Laws, 31 Cal. 2d 846, 193 P.2d 744 (1948) ; Amschler v. Remijasz, 341 Il. App. 262, 93 N.E.2d 386 (1950).

59334 U.S. at 13.

60 See, e.g., cases cited at note 58 supra.

61 Compare Roberts v. Curtis, 93 F. Supp. 604, (D.C. 1950), and Phillips v. Naff, 332 Mich. 389, 52 N.W.2d 158 (1952) (daunages demed), with Correll v. Earley, 205 Okla. 366, 237 P.2d 1017 (1951), and Weiss v. Leaon, 359 Mo. 1054, 225 S.W.2d 127 (1949) (dainages allowed). See Groves, Judicial Interpretation of the Holdings of the United States Supreme Court in the Restrictive Covenant Cases, 45 Irr. L. REv. 614 (1950). 
was settled affirmatively in Barrows v. Jackson, ${ }^{62}$ the Supreme Court re-emphasizing the scope of the "judicial enforcement" doctrine. However, other problems are not settled. Since the covenant itself is "valid," may it be raised as a defense against an assertion of title by a Negro purchaser? ${ }^{63}$ And since the covenant is unenforceable, should its mere presence be allowed as a means to aid a Negro purchaser in repudiating a contract to buy? ${ }^{64}$ These are only some of the issues remaining concerning racially restrictive covenants. ${ }^{65}$

Aside from the restrictive covenant cases, the general attitude of the courts

62346 U.S. 249 (1952). For an excellent discussion of the problems raised by this issue, see Barrows v. Jackson, 112 Cal. App. 2d 534, 247 P.2d 99 (1952).

Vinson, C.J., author of the opinion in Shelley v. Kraemer, dissented in Barrows v. Jackson. Besides arguing that according to the rules of the Court the defendant, the white vendor who had violated the covenant, had no standing to raise the issue of a violation of Negro rights, he urged that on the merits no one's rights were violated by awarding damages for a breach of the covenant. Justice Vinson argued that Shelley did not prevent all enforcement of racially restrictive covenants, but only such enforcement which resulted in the violation of rights protected under the fourteenth amendment. When the covenant is cnforced between the parties there is no violation of the fourteenth amendment simce the state is not coercing the Negro in order to deprive him of his rights.

An advance clue that this might have been Justice Vinson's conception when writing Shelley might be found in the following passage from his opinion in Hurd v. Hodge: "It is not consistent with the public policy of the United States to permit federal courts in the Nation's capital to exercise general equitable powers to compel action denied the state courts when such state action has been held violative [of the fourteenth amendment in Shelley v. Kracmer]." Hurd v. Hodge, 334 U.S. 24, 35 (1948). (Emphasis added.) Why did not the distinctions drawn in Barrows and hinted at in Hurd appear in Shelley?

63 Only one reported case has been found dealing with this problem in regard to racial restrictions against sale and use of land. Chifton v. Puente, 218 S.W.2d 272 (Tex. Civ. App. 1948), demed the right to raise the covenant as a defense against a purchaser's assertion of ownership. "It is as much an enforcement of the covenant to deny to a person a legal right to which he would be entitled except for the covenant as it would be to expressly command by judicial order that the terms of the covenant be recognized and carried out." Id. at 274.

But see Rice v. Sioux City Memorial Park Cemetery, 245 Iowa 147, 60 N.W.2d 110 (1953), aff'd per curiam without opinion by an equally divided court, 348 U.S. 880 (1954), but judgment vacated, 349 U.S. 70 (1955), 44 CAIIF. L. REv. 153 (1956). Plaintiff had signed a contract with defendant cemetery to bury her Indian husband. The contract contained a covenant against the burial of non-Caucasians. When it learned of the deceased's ancestry the defendant refused to perform and escaped hability by defending on the covenant. "[A]ll of the previous decisions unay be distinguished from our present case in that they disclose the exertion of governmental power directly to aid in discrimination, or other deprivation of right. Certainly, that factor is not presented here where the state has maintained neutrahty." And further, "It is clear that state action ... has only been expanded to direct action . . . to aid in the enforcement of restrictive or discriminating acts or agreements." Id. at 155,157, 60 N.W.2d at 115, 116. Are Clifton and Rice contrary in their uses of the Shelley doctrine? Is it not significant that in Clifton a refusal to follow Shelley would have resurrected defunct private discrimination, while in Rice such refusal served only to admit the existence of private discrimnation otherwise effective?

64 Savage v. Parks, 100 A.2d 450 (Mun. App. D.C. 1953), allowed a Negro purchaser, who signed his contract after the rendition of Hurd v. Hodge, 334 U.S. 24 (1948), to rescind upon learning of the existence of a restrictive covenant in the chain of title. This fact was held material, even though the covenant was "unenforceable," since the purchaser would not be forced to "borrow trouble" from the unsettled condition of the racially restrictive covenant. Accord, Cohn v. Trawick, 60 A.2d 926 (Mun. App. D.C. 1948) (contract signed prior to Hurd v. Hodge but suit subsequent to it).

65 See also Claremont Improvement Club. v. Buckingham, 89 Cal. App. 2d 32, 200 P.2d 47 (1948) (refusal to render a declaratory judgunent on the validity of a covenant per se) and Gaddis Investment Co. v. Morrison, 3 Utal 2d 4, 278 P.2d 284 (1954) (refusal of real estate agent to consumate a sale in violation of a covenant until he received approval from a local real estate board was not as a inatter of law an abandonment of his contract and forfeiture of his commission). 
is illustrated in another decisional area. Dorsey v. Stuyvesant Town Corp. ${ }^{68}$ presents a clear example of how a court first found the instrumentality theory inapplicable and then avoided the application of the doctrine of judicial enforcement. Pursuant to a state law designed to give impetus to the building of housing by private business firms, the defendant Metropolitan Life Insurance Company contracted with the city of New York to build through Metropolitan's subsidiary, defendant Stuyvesant Town Corporation, a lousing project capable of accomodatimg about twenty-five thousand people. No state policy was announced as to the restriction of tenants, and the defendants excluded Negroes. Plaintifis, Negroes, sued to enjoin such discrimination on the grounds that it violated the fourteenth amendinent. Despite the facts that the erection of the project was part of a state policy to create lousing and effect land reliabilitation, that the state gave aid in the nature of eminent domain, loans and tax exemptions, and that the state supervised througl regnlar inspections, maximum rentals and financing regnlations, a majority of the New York Court of Appeals were unwilling to find sufficient state action to bring defendants' acts under the amendment. Resting its decision on the statutory declaration that no state subdivision was authorized to engage in lousing of the Stuyvesant variety, the court concluded that while there was government aid and control, there was no government intervention-hence no state action in the project itself. ${ }^{67}$

Whether or not one agrees with this analysis, ${ }^{68}$ the important point to remeinber is that its thrust goes only toward disproving that neither by state aid, ${ }^{69}$ nor by the exercise of a public function, ${ }^{70}$ were the acts of the defendants considered acts of the state. The court in Dorsey fails to ineet the proposition that, by failing to provide plaintiffs with a remedy against the discrimination and thus giving sanction to the discrimination, the court itself denied plaintiffs the equal protection of the laws under the doctrine of judicial enforcement. ${ }^{71}$

60299 N.Y. 512, 87 N.E.2d 541 (1949), cert. denied, 339 U.S. 981 (1949); accord, Estate of Girard, Pa. Orph. Ct., Phila. County (1955), 1 Race ReIat. L. Rep. 325 (April 1956), aff'd en banc, 1 Race ReLat. L. ReP. 340, aff'd, 25 U.S.L. WEEK 2214 (Pa. Nov. 12, 1956); cf. J6hnson v. Levitt, 131 F. Supp. 114 (E.D. Pa. 1955).

07 "The aid which the State has afforded to [defendants] ... and the control to which they are subject are not sufficient to transmute their conduct into State action under the constitutional provisions here in question." 299 N.Y. at 536, 87 N.E.2d at 551.

68 Three judges dissented in Dorsey. Fuld, J., presents a concise picture of cooperation hetween the State and the defendants. Though it cites Shelley v. Kraemer several times, the dissenting opinion is concerned, not with the judicial enforcement theory, but ouly with its disagreement with the majority opinion on the application of the instrumentality theory. See also Note, 29 NEB. L. REv. 470 (1950).

69 See note 15 supra.

70 Marsh v. Alabama, 326 U.S. 501 (1946); see text at note 31 supra.

71 For decisions having the same fault of ignoring the judicial enforcement theory after dealing with the older state action doctrines, see Easterly v. Dempster, 112 F. Supp. 214 (E.D. Tenn. 1953); Norris v. Baltimore, 78 F. Supp. 451 (D.Md. 1948); cf. Wilcox v. Horan, 178 F.2d 162 (10th Cir. 1949); Syres v. Oil Workers Int'l, Local 23, 223 F.2d 739 (5th Cir. 1955), reversed, 350 U.S. 892 (1955).

Cf. Hallmark Productions v. Mosley, 190 F.2d 904 (8th Cir. 1951), and Johnson v. Middleton, 175 F.2d 535 (7th Cir. 1949). In both cases the plaintifis sued, inter alia, for equitable rehef under federal statutes promulgated under the fourteenth ainendment; in both the contentions were dismissed for want of proper allegations. In view of the abrupt treatment of Shelley $v$. Kraemer in Johnson, and of the reliance on Johnson by Hallmark (190 F.2d at 90809 ), one doubts that if the allegations had been proper so as to raise the issue, the judicial enforcement theory would have had any effect. "Appellants contend that ... they also imvoked [the statutes] for the protection of their rights as Negroes to own and occupy land, citing 
But of far more interest than the cases where pre-Shelley doctrines might have fit are those where they would not. Where activities forbidden the states by the fourteenth amendment are carried on by purely private parties, activities which the older theories are incapable of reaching, has the Shelley doctrine been used to protect civil rights? Many commentators proclaimed Shelley would have an important effect here, ${ }^{72}$ drawing, for example, close parallels between restrictive covenants and other private means of restricting land ownership, such as the fee simple determinable with the right of reverter or the right of re-entry upon breach of a condition subsequent. ${ }^{33}$ Here agaim the courts have been reluctant to give effect to the doctrine of judicial enforcement.

The cases most clearly illustrating the problein are three decisions in which suits were instituted to determine the validity of the privately created discrimination and in which the courts recognized the validity of such private action. ${ }^{74}$ One of these is especially indicative. In Charlotte Park and Recreation Comm'n v. Barringer ${ }^{75}$ the plaintiff, a corporate public body, received inter alia as a deed of gift from the mdividual defendant certain property to be used as a public park on the condition that it be restricted to the exclusive enjoyment of "persons of the white race." The deed provided that if this condition were violated the property would revert to the grantor, his heirs or assigns, provided le paid a certain sum. Plaintiff sued for a declaratory judgment on the validity of the discrminatory condition in the deed. Emphasizing the fact that the deed created a possibility of reverter, ${ }^{76}$ by which title returned to the grantor with no activity required by him or the court, the North Carohina supreme court upheld the trial court's declaratory judgment that there was no state action in violation of the fourteenth amendment. ${ }^{77}$ Since the decision merely declared the validity of the reverter, it does not directly allow racial discrimination since the commission, a public body, may not discriminate under orthodox state action concepts and,

Shelley v. Kraemer [citation omitted] which involved the question of restrictive covenants. Here we have no issue revolving upon restrictive covenants. It is not in point." Johnson v. Middleton, supra at 538.

72 See, e.g., Huber, Revolution in Private Law?, 6 S.C.L.Q. 8, 25-29 (1953) ; Ming, Racial Restrictions and the Fourteenth Amendment: The Restrictive Covenant Cases, $16 \mathrm{U}$. CH. I. REv. 203 (1949) ; Note, 24 N.Y.U.L.Q. 227 (1949).

73 Various alternatives to the covenants are described in Scanlon, Racial Restrictions in Real Estate, 24 Notre DaMe Law. 157, 181-89 (1949); Comments, $43 \mathrm{Ky}$. L.J. 151, 159-62 (1954), 1952 U.C.L.A. INTRA. L. Rev. 14, 16-18; Note, 37 MINN. L. Rev. 65, 66 n.7 (1952). Analyzing the practical as well as the legal aspects of the alternatives, the writers appear unanimous in concluding that if any of these substitutes reach a court, it would be declared invalid under Shelley v. Kraemer.

74 Gordon v. Gordon, 332 Mass. 197, 124 N.E.2d 228 (1955), cert. denied, 349 U.S. 947 (1955) (gift-over if legatee married outside Hebrew faith); Charlotte Park and Recreation Comm'n v. Barringer, 242 N.C. 311, 88 S.E.2d 114 (1955), cert. denied, 350 U.S. 983 (1956) (deed requiring property to revert to grantor if used by non-Caucasians); United States Nat'l Bank v. Snodgrass, 202 Ore. 530, 275 P.2d 860 (1954) (gift-over if legatee married person of Cathohic faith); cf. Junkins v. Local 6313, Communications Workers, CIO, 263 S.W.2d 337 (Mo. 1954) (court refusal to review action of a labor union because it is not a private party). 75242 N.C. 311, 88 S.E.2d 114 (1955), cert. denied, 350 U.S. 983 (1956). See Notes, 27 MIss. L.J. 145 and 3 U.C.L.A.L. REv. 243 (1956), where it is argued that the decision violates the doctrine of judicial enforcement. But see Notes, 13 WASH. \& LEE L. REV. 28 (1956) and 17 U. PITT. L. REv. 478 (1956).

76 As to the technical correctness of this proposition, see Note, 34 N.C.I. REv. 113 (1955).

77 Plaintiff had also received a deed with similar provisions of reverter from the city of Charlotte. Trial court held that this provision did violate the fourteenth amendment and was invalid. This ruling was not appealed. Charlotte Park and Recreation Comm'n v. Barringer, 242 N.C. 311, 323, 88 S.E.2d 114, 124 (1955). 
realistically, is probably forced to return the property. ${ }^{78}$ But this point aside, it is submitted that the decision leaves unanswered certain questions raised by Shelley v. Kraemer. Though the Barringer decision attempts to ineet Shelley squarely and to distinguish it along the lines of the judicial enforceinent doctrine, it fails in its task: the problem of state action here is not merely whether title passes independently of a court decision; the questionable state action in this case is the declaratory judgment by which-in apparent violation of Shelley-the court applies its sanction to a discriminatory instrument. ${ }^{79}$ Furthermore, if in a subsequent case a grantee of a deed snbject to this sort of provision (or his non-white purchaser) refused to give up possession to the grantor, would not Barringer be used to substantiate an argument that since title has already returned to the grantor, the courts may iguore the discriminatory reasons for the return and aid him in his suit for repossession?" If so, is not the "full coercive power of government" being made available to individuals to further their discriminatory acts?

Thus an analysis of the cases subseqnent to Shelley v. Kraemer makes it clear that, aside from the racially restrictive covenant cases, the courts will not carry out the doctrine that court aid to all private discrimination is state discrimination. If the situation appears to fit within the pre-Shelley doctrines of state action, the courts will analyze it along those lines and decide only on those grounds, either ignoring or failing to ineet Shelley. If the case concerns what was undoubtedly private action before Shelley, private action it remains. Admittedly the Supreme

78 Compare this distinction with the fact that where the public body was the grantor there was discriminatory state action. See note 77 supra.

See Note, 104 U. PA. L. REv. 421 (1955), where it is argued that the court should have declared the condition void under property concepts.

79 That Shelley $v$. Kraemer declared racially restrictive covenants to be valid per se is no answer to this contention. There is a difference between sucls dictum and a declaratory judgment. "The declaratory judgment comprises an authoritative judicial statement of the jural relationships between parties to a controversy. It does not itself, however, have any direct coercive effect." But further, "[S]ince the 'non-coercive' declaratory judgment is res judicata, it may serve as the basis for a subsequent equitable decree or judgment at law. This possibility of further relief gives, in practice, an immediate coercive effect to the declaration itself." $D e$ velopments in the Law, Declaratory Judgments-1941-49, 62 HARv. L. REv. 787, 788-89 (1949). (Citations omitted.) See Claremont Improvement Club v. Buckingham, 89 Cal. App. 2d 32,200 P.2d 47 (1948) (declaratory judgment sustaining validity of racially restrictive covenant refused).

80 Cf. Novick v. Levitt \& Sons, 200 Misc. 694, 108 N.Y.S.2d 615 (Sup. Ct. 1951). Plaintiff tenant sued to restrain defendant landlord from recovering possession of the premises upon expiration of the lease. The plaintiff charged that the landlord's refusal to renew the lease was based on reasons of racial discrimination. Defendant's motion to dismiss was granted. The court stated that even if this charge had been properly before the court (which the court held it was not) it would not have stated a cause of action since there is no legal theory which denied a landlord who is a private person the right to choose his tenants. Id. at 696-97, 108 N.Y.S.2d at 617; accord, Metropolitan Life Ins. Co. v. Davis (N.Y. Unrep. 1951); Stuyvesant Town Corp. v. Berg (N.Y. Unrep. 1951), aff'd, 126 N.Y.L.J. 1008 col. 4 (App. Div. Oct. 25, 1951). These last two cases allowed landlords to dispossess tenants in the face of the clain that the actions were due solely to racial discrimination. They are discussed in Rodger, Life Insurance Investments: Some Legal Phases, 40 A.B.A.J. 676, 679 a.18 (1954).

Assuming racial discrimmation were present, these cases clearly show court action abetting it. But is there not a difference between a situation, as in Shelley, where in the absence of court action the private discrimination would be ineffective and one where, as in the landlordtenant cases, the private discrimination would become effective without court action designed to aid it. Even if the landlord were to sue the tenant, this distinction is valid. If the lease itself is validly defunct, the tenant no longer lias any right to remain. Can the nere presence of private racial discrimination give him such rights? It would be different, of course, if the lease were-except for a racial clause-still in effect. 
Court has not determined the matter. But certiorari was denied to Dorsey v. Stuyvesant Tozen Corp. im 1949 and to Gordon v. Gordon ${ }^{81}$ in 1955. And note that Rice v. Sioux City Memorial Park Cemetery ${ }^{82}$ was affirmed (if only by an equally divided court) in 1954 though this judgment was later vacated. Admittedly, little can be drawn from a denial of certiorari in any single case. ${ }^{83}$ and two denials may not establish a trend, but nonetheless in absence of other evidence it is reasonable to conclude that the Supreme Court is reluctant to carry Shelley forward.

\section{What Is the Value of Shelley v. Kraemer Today?}

Since there is a growing public and professional interest in the role of legal institutions in the solution of conteunporary social problems, the Court's decisions [in the restrictive covenant cases] should be evaluated in terms of their effect on racial segregation and the constitutional theories with respect to the protections afforded to members of minority groups.84

These words, written by a proponent of the full implications of the decision in Shelley v. Kraemer, ${ }^{85}$ fix attention on the fact that there is more involved in the case than placing a further limitation on racial discrimination. Also present are important issues of constitutional theory. The sharpest illustration of the problem facing us is the fact that, as shown above, of the cases subsequent to Shelley, aside from the restrictive covenant cases, not one reported decision has been found that followed the doctrine of judicial enforcement. In light of Shelley many of these cases are "illogical." But this very reluctance to follow Shelley should warn the legal commentator that before he can condemn these cases he must give consideration to the reason behind their position. It is submitted that the reasons for this judicial attitude is that Shelley, as a result of the potentially broad sweep of its doctrine, ${ }^{86}$ raises grave constitutional problems in two areas: ${ }^{87}$ (1) It upsets the balance of federal-state relationships by giving an enormous

81332 Mass. 197, 124 N.E.2d 228 (1955), cert. denied, 349 U.S. 947 (1955); see note 74 supra. Certiorari was also demied to the Barringer decision, 350 U.S. 983 (1956). But this may have been due to the special circumstances of the case. See text at note 78 supra.

82245 Iowa 147, 60 N.W.2d 110 (1953), aff'd without opinion, 348 U.S. 880 (1954), but judgment vacated, 349 U.S. 70 (1955), 44 CaLIF. X. REv. 153 (1956); see note 62 supra.

83 For a general discussion of the Court's attitude concerning writs of certiorari, see Gibbs, Certiorari: Its Diagnosis and Cure, 6 Hastings L.J. 131 (1954). The author's views on why certiorari was denied in Dorsey illustrate the problem. Id. at 147-48. For a discussion of the problems surrounding certiorari in a particular area, when there is a conflict among the circuits, see Stern, Denial of Certiorari Despite a Conflict, 66 HARv. L. REv. 465 (1953).

84 Ming, Racial Restrictions and the Fourteenth Amendment: The Restrictive Covenant Cases, 16 U. Car. L. REv. 203, 207 (1949).

85 See note 54 supra.

86 That the sweep of the hiteral meaning of Shelley $v$. Kraemer is too broad is illustrated by the assumptions of certain writers that future decisions must place limitations. E.g., Frank, The United States Supreme Court: 1947-48, 16 U. CEr. L. REv. 1, 23-24 (1948); Groves, Judicial Interpretation of the Holdings of the United States Supreme Court in the Restrictive Covenant Cases, 45 IrL. I. Rev. 614, 626-27 (1950); Hyman, Segregation and the Fourteenth Amendment, 4 VAND. L. Rev. 555, 569-71 (1951); Comment, 48 Colum. L. Rev. 1241, 1244 (1948). Some writers have endeavored to find limitations withm the Shelley doctrine. See text at note 93 infra.

87 That these are problems with which the courts are concerned is shown by Rice v. Sioux City Memorial Park Ceinetery, 245 Iowa 147, 155-56, 60 N.W.2d 110, 115 (1953); Dorsey v. Stuyvesant Town Corp., 299 N.Y. 512, 534-35, 87 N.E.2d 541, 550-51 (1949); and United States Nat'l Bank v. Snodgrass, 202 Ore. 530, 536-39, 275 P.2d 860, 863-64 (1954). 
opportunity for federal activity in the civil rights area; (2) it poses definite problems concerning the relationship of the individual to his government.

Recent history has produced enough on the first problein; this Comment need not discuss it further. Suffice it to say that this would not be the only area where the federal-state relationship has been "upset." 88 But consider this one question: If failure to provide a judicial remedy, an example of inaction, is now a form of state action, are other forms of state inaction also to be so included, thus giving the federal government greater authority to act under the "enabling clause" of the fourteenth amendment? ${ }^{89}$

The other problem involves issues which deserve inore consideration here. If obtaining court aid to carry out "private" activity "converts" such private action into "state" action, then there could never be any private action in any practical sense. So entwined are our lives with the law ${ }^{00}$ that the logical result would be that almost all action, to be effective, inust result in state action. ${ }^{91}$ Thus all private activity would be required to "conform" with the standards of conduct imposed on the states by the fourteenth ainendment. Under the guise of protecting civil rights by "strengthening" due process and the equal protection of the laws, is it not possible that Shelley creates a means of restricting civil liberties, making possible far greater government control of individual activity than desired ? $^{92}$

88 Compare the growth of the power of the national government under U.S. ConsT. art. I, $\$ 8$, cl.3, the "Commerce Clause." But see Dorsey v. Stuyvesant Town Corp., 299 N.Y. 512, 534,87 N.E.2d 541, 551 (1949), where the court argues that the extension of national power into the field of individual rights to become the primary arm of enforcement is unwise.

80 U.S. Const. amend. XTV, $\S 5$, quoted at note 2 supra. See note 18 supra. But note these words in Shelley: "These are not cases, as has been suggested, in which the States have merely abstained from action, leaving private imdividuals free to impose such discriminations as they see fit. Rather, these are cases in which the States have made available to such individuals the full coercive power of government ...." Shelley v. Kraemer, 334 U.S. 1, 19 (1948). Is the inference that if the state had "abstained from action" that the fourteenth amendment would not have been violated, or are these words to be taken only as emphasis, as contrast to the Court's conclusion? One writer concludes the former is correct. Huber, Revolution in Private Law?, 6 S.C.L.Q. 8, 29-30 (1954).

80 Professor Hyman points out that there are other means of law enforcement of private action, besides that of the courts, that would be state action under the Shelley approach. Hyman, Segregation and the Fourteenth Amendment, 4 VAND. L. REv. 555, 565-67 (1951).

01 See Lathrop, The Racial Covenant Cases, 1948 WIs. L. REv. 508, 513-15, and Scanlan, Racial Restrictions in Real Estate, 24 Notre DaAne LAw. 157, 172-74 (1949), which espouse the doctrine that the enforcement of "private law" is state action. If so can there ever be any significant "private action" in any practical sense? The issue is not the logic of the proposition but whether we wish to adopt it.

82 Professor Cahn points out that we must distinguish between "official and unofficial" discrimination, the latter being tolerable even in a political democracy. "When we resolve to observe the primciples of the Constitution in every activity that is sponsored or controlled by government, our ability to do so in a willing and congenial manner may well depend on our being free, spontaneous, and unhampered in the remainder of our relationships.... Discrimination in regard to corporate advantage (such as transportation, housing, employment, political franchise, or educational opportunity) violates the American promise; but discrimination in the choice of friends and associates may furnish the very safety valve that many Americans require for psychic health." Cahn, Jurisprudence, 30 N.Y.U.L. REv. 150, 156 (1955). Considering the phrase "psychic health," note the irrational reaction in many Southern quarters to the School Segregation Cases, a reaction that goes beyond mere disagreement on constitutional or policy grounds. For a discussion similar to Professor Cahn's, but in another area, see United States Nat'l Bank v. Snodgrass, 202 Ore. 530, 536-39, 275 P.2d 860, 863-64 (1954).

But cf. Wilson, The Merging Concepts of Liberty and Equality, 12 WASH. \& LeE L. REv. 
Given these dangers, does the doctrine of Shelley $v$. Kraemer itself provide internal limitations? The writers have presented primarily three theories of limitation: (1) That Shelley means only that one person cannot use the courts to compel another person to commit an act forbidden the states by the fourteenth amendment; ${ }^{93}$ (2) that Shelley applies only if a court fails to provide a remedy for a right protected by that amendinent where the state had the constitutional power to provide a remedy in other ways; ${ }^{04}$ (3) that Shelley is inapplicable "where the necessity of protecting the property right [or any other personal activity?] outweighs the need for safeguarding the civil right," a "balancing of interests" approach. ${ }^{95}$

The first of these three is the only concrete limitation, for it excludes from application situations where the individual wants to use a court to enforce his own prejudicial action without requiring another to discriminate also. This would explain Rice v. Sioux City Memorial Park Cemetery ${ }^{96}$ and Dorsey v. Sturyvesant Towen Corp., ${ }^{97}$ the instrumentality theory having failed. But while definite, is this a realistic limitation considering the wide terms in which Shelley speaks? ${ }^{08}$ Even Professor Hyman expresses a doubt: "[T]here is the question whether this limitation goes far enougl to serve the purposes of the Fourteenth Amendment."

The other two proposed himitations lack all the virtue of the first. What is the limit of the state's power to prevent private violations of rights protected by the fourteenth amendment? And how does one decide that the violation of a civil riglit is to be countenanced in order to preserve the freedom of some personal action? These are problems the courts have long had to deal with, and limitations having these problems as their foundation create only ephemeral delineations.

The writer, submits, however, that there is another theory of limitation to be found within the doctrine of judicial enforcement as espoused by Shelley $v$.

182 (1955). The argument there is that, contrary to the traditional view, the concept of equality of opportunity (i.e., "equal protection of the laws") is not antithetical to that of liberty of action. Equality becomes a means of creating greater liberty for more. Of course, the problem is illustrated in Shelley $v$. Kraemer: equality of opportunity gives the Negro greater liberty to hold realty; however, at the same time this equality restricts the white landowner in bis liberty to contract. This is fine for restrictive covenants. But, as Professor Wilson relaizes, the real problem is that at some point in the egalitarian society liberty becomes meaningless-this is the problem raised by Shelley. Contra, Huber, Revolution in Private Law?, 6 S.C.L.Q. 8 (1954).

93 Hyman, Segregation and the Fourteenth Amendment, 4 VAND. L. REv. 555, 569 (1951); cf. Vinson, C.J., dissenting in Barrows v. Jackson, 346 U.S. 249, 260 (1952), note 62 stıpra. (1951).

94 Hyman, Segregation and the Fourteenth Amendment, 4 VAND. L. REv. 555, 569-71

05 Comment, 48 Coldur. L. Rev. 1241, 1244-45 (1948); see Hate, Freedom throuor LAW 370-72, 376, 380-81 (1952); Comment, 96 U. PA. L. Rev. 402, 413-14 (1948). Sce also Groves, Judicial Interpretation of the Holdings of the United States Supreme Court in the Restrictive Covenant Cases, 45 IrL. L. Rev. 614, 626-27 (1950). The author seeks to show limits in Shelley by arguing that certain decisions upholding transactions based on racially restrictive covenants would still be upheld under Shelley. However, the basis of his distinctions is not clear.

06 See note 62 supra.

97 See text at note 66 supra.

98 "The difference between judicial enforcement and nonenforcement of the restrictive covenants is the difference to [defendants] between being denied rights of property availablo to other members of the community and being accorded full enjoyment of those rights on an equal footing." Shelley v. Kraemer, 334 U.S. 1, 19 (1948). These words apply to Clifton v. Puente, 218 S.W.2d 272 (Tex. Civ. App. 1948), supra note 61, where no one was being compelled to discriminate, and to Barrows v. Jackson, 346 U.S. 249 (1952), text at note 62 supra.

09 Hyman, Segregation and the Fourteenth Amendment, 4 VAND. L. REv. 555, 569 (1951). 
Kraemer. This approach is submitted in the belief that it reconciles Shelley with its subsequent decisions and presents a guide by which the courts may be able to. apply the doctrine of judicial enforcement instead of avoiding it.

It is submitted that the doctrine of judicial enforcement as interpreted by Shelley is applicable only when the court action abets private discrimination which in the absence of such judicial aid would be ineffective. Judicial enforcement of private discrimination, not judicial recognition, is prohibited. ${ }^{100}$ Where the private activity, admitted in Shelley to be valid in itself, is already effective, it is not to be said that the court, in recognizing or failing to abolish the activity, is itself an arm of the discrimination; the situation has remained the same, court action or no. It is only where the proponents of discrimination, unable to further their ends privately, seek court aid is the state itself causing discrimination under Shelley.

In Shelley the status quo was non-discriminatory, that is, the Negroes were already in control of the disputed property as a matter of right. The only bar to their title and control was the discriminatory clause, now ineffective. Only by court action could the occupants be ousted. ${ }^{101}$ But the cases subsequent to Shelley presented the converse situation. Private discrimination was always a fait accompli, effective without court aid. In Dorsey, for example, the plaintiffs had already been effectively deprived of entrance before the complaint was ever filed. In Barringer the status quo was discriminatory, that is, the parties injured thereby had already been effectively deprived by the private acts. The declaratory judgment, while carrying the force of law, ${ }^{102}$ only admitted what Shelley expressed, ${ }_{9}^{103}$ that the private action was in itself vahd. ${ }^{104}$

The recent Supreme Court decision of Black v. Cutter Laboratories ${ }^{105}$ may be an indication that a view such as this may be adopted. Plaintiff was discharged from her employment on the grounds that her continuing membership in the Communist Party was "just cause" for dismissal under a collective bargaining agreement. The Supreme Court of California held such a discharge to

100 In his dissent in the Cutter case Douglas, J., states: "If the courts lend their support to any ... discriminatory prograin, Shelley v. Kraemer . . . teaches that the Government has thrown its weight behind an unconstitutional scheme ...." Black v. Cutter Laboratories, 351 U.S. 292, 302-03 (1956) (Emphasis added.). But there is, it is submitted, a distinction between the government "throwing its weight behind" an already effective discriminatory program, on the one hand, and doing the same thing to an otherwise ineffective program, on the other. The latter is enforcement. The latter is unconstitutional under the Shelley doctrine; the former may not be.

101 " $[B]$ ut for the active intervention of the state courts . . . defendants would have been free to occupy" their property. 334 U.S. at 19. (Emphasis added.)

102 See note 79 supra.

103 See text at note 55 supra.

104 Admittedly an anomaly is presented. Even if the discriminatory party receives a declaratory judgment in his favor, this analysis of Shelley would prevent him from suing on it if the status quo, but for the declaratory judgment, is non-discriminatory. The anomaly may arise from the nature of the original suit for the declaratory judgment, in which (since it is often anticipatory) the parties to the real controversy are often reversed. If landlord $A$ sues tenant $B$ to declare that $B$ has no right on the premises, in reahty this is in anticipation of $B$ 's later suit to establish his right. If $B$ 's claim is based solely on $A$ 's racial discrimination and not on some lease, etc., then $B$ has no right and $A$ 's declaratory judgment establishes this. For illustrative discussions of the problem of "reversed parties," see E. Edelmann \& Co. v. Triple-A Specialty Co., 88 F.2d 852 (8th Cir. 1937), and Developments in the Law, Declaratory Judgments1941-49, 62 HARV. L. REV. 787, 802-03 (1949).

105351 U.S. 292 (1956). 
be valid under local contract law. ${ }^{106}$ The Supreme Court dismissed the writ of certiorari for want of a federal question, reasoning that only a question of local law was involved. The dissent, written by Justice Douglas, urged that a classification based on party membership is forbidden the government under the Constitution so that when a state court recognized such a classification, a violation of the fourteenth amendment occured. ${ }^{107}$ Admitting the major premise of the dissenting argument, it is not necessary to conclude that the Shelley doctrine has been violated: Here was a clear case of private discrimination being effective without state action. And since the majority in the Black case must lave been aware of the dissenting argument, is not the lolding that there was no federal question in reality a decision that in such a situation Shelley will not be applied?

\section{Conclusion}

Shelley v. Kraemer, though standing as a landmark decision in our constitutional history, las thus far been denied much practical judicial importance by its treatment in subsequent cases. The reason is clear: the wide sweep of the doctrine of judicial enforcement has caused judge and writer alike to wonder. Given the present judicial attitude-a failure to give us a guide by which Shelley can be used-the case is of no use as an important constitutional decision outside the field of racially restrictive covenants, for no court may be willing to apply it elsewhere. Yet so important a decision should not be lost. It is suggested that much can be done to preserve its importance by an analysis along the lines lerein suggested. In this way it may be possible that the decision can remain a powerful weapon for the protection of civil liberties without remaining a potential danger as a limitation on personal activity.

Donald M. Cahen

10643 Cal. 2d 788, 278 P.2d 905 (1955).

107351 U.S. 292, 301-02 (1956); see note 54 supra. 